\title{
Is modern genetics the new eugenics?
}

\author{
Charles J. Epstein, MD
}

On April 25th of this year [2003], we celebrated the fiftieth anniversary of the elucidation of the structure of DNA by Watson and Crick, an accomplishment of which we are all extremely proud - and justifiably so. A vast amount is being written and said about the significance of this discovery and about where genetics in general, and human genetics in particular, are now and where they are going. The Royal Mail of the United Kingdom even issued a set of stamps to honor the occasion as well as the completion of the Human Genome Project. The stamps feature cute cartoons about genetics, and the cancellation on the first day cover uses a quotation from James Watson: "Our fate is in our genes" (Fig. 1). This is an interesting choice, because to many human geneticists this notion has a very deterministic ring about it, one from which they are trying to distance themselves.

Along with the celebration, there has been much speculation about what the future will bring. For example, the next 50 years will bring, according to Time's consultants, food without fat, cellular therapies and new organs, the $\$ 100$ personal genome, slowing of the aging process, germ-line genetic engineering, and reverse engineering of the human brain. ${ }^{1}$ As might be expected, speculations such as these have engendered considerable concern- how much, how fast? ${ }^{2}$ What are the ethics and morality of making new and better babies? Is this a return to the eugenics thinking of the past?

In 1990, in a book describing his view of human genetics, Berkeley sociologist Troy Duster spoke about a back door to eugenics, one that is made up of "screens, treatments, and therapies," 3 and a few years later, Arthur Dyck, a professor of ethics at Harvard, wrote the following: Science, medicine and law at present willingly provide the information, rationale, and technical know-how for current eugenic practices in the United States, some of them quite coercive and arguably unethical. . . Eugenics is not simply a matter of history. Eugenics is practiced today. . . [and] the very ideas and concepts that informed and motivated German physicians and the Nazi state are in place. ${ }^{4}$

Dyck and Duster were not alone in telling us that eugenics is actively being pursued in the practice of human and medical genetics. For example, Dorothy Wertz said it outright: "Eugenics is alive and well." 5 The basis for her assertion is that,

\footnotetext{
The ACMG presidential address was presented March 13, 2003 at the 2003 Annual Clinical Genetics Meeting of the American College of Medical Genetics, San Diego, California.

From the Department of Pediatrics, University of California, San Francisco

Charles J. Epstein, MD, Department of Pediatrics, U585L, University of California, San Francisco, 533 Parnassus, San Francisco, CA 9443-0748.
}

DOI: 10.1097/01.GIM.0000093978.77435.17 whereas only some geneticists regard what they are doing as being eugenics, counseling for prenatal diagnosis is "pessimistically biased" or "slanted" and counselors have a "pessimistic view of persons with disabilities,"-perhaps not so much in the English-speaking countries, but certainly in the rest of the world. Similarly, Science, in reporting a survey on cloning, tells us that "eugenics is gaining broader acceptance overall," in this instance equating eugenics with prenatal diagnosis for desirable traits and the use of genetic engineering to produce these traits. ${ }^{6}$ And, in a comment cited in an article reporting that the governor of Virginia recently apologized for Virginia's 1924 law authorizing involuntary sterilization for eugenic purposes, Barbara Bieseker is quoted to the effect that prenatal diagnosis may be operating in a "milieu of personal eugenics."7

The worst accusation that can be leveled against modern human genetics and medical genetics is that they are eugenic-if not a literal return to the eugenics of the past, at least a reincarnation of that eugenics in a new guise. The mere use of the word "eugenics" brings forth very visceral responses. Richard Dawkins, of The Selfish Gene fame, tells us that, "If cannibalism is our greatest taboo, positive eugenics. . . is a candidate for the second. . . In our time, the word [eugenics] has a chilling ring. If a policy is described as 'eugenic,' that is enough for most people to rule it out at once. ..." And, according to Diane Paul, "the term is wielded like a club. To label a policy 'eugenics' is to say, in effect, that it is not just bad but beyond the pale."9

\section{How should we respond?}

I must confess that I was quite taken aback when I first heard human genetics being equated with eugenics. Indeed, several years ago when the American Society of Human Genetics was discussing the 1994 Chinese eugenics law, ${ }^{10}$ it did not really occur to me that anyone would construe what human and medical geneticists were doing in the United States as being eugenic. My first response was to deny the eugenics association out of hand, thinking that it might be more an issue of semantics than of substance. Then, when I began to look further into the matter, I went through a period of self-doubt and disbelief, perhaps even guilt, and I found myself beginning to identify with the critics and to question everything that I had taken for granted.

However, with the passage of time, I regained my sense of balance and, while acknowledging that the critics have raised many important issues, came to the conclusion that the human genetic enterprise is basically sound. I also came to the realization that if human and medical geneticists are to make an ef- 

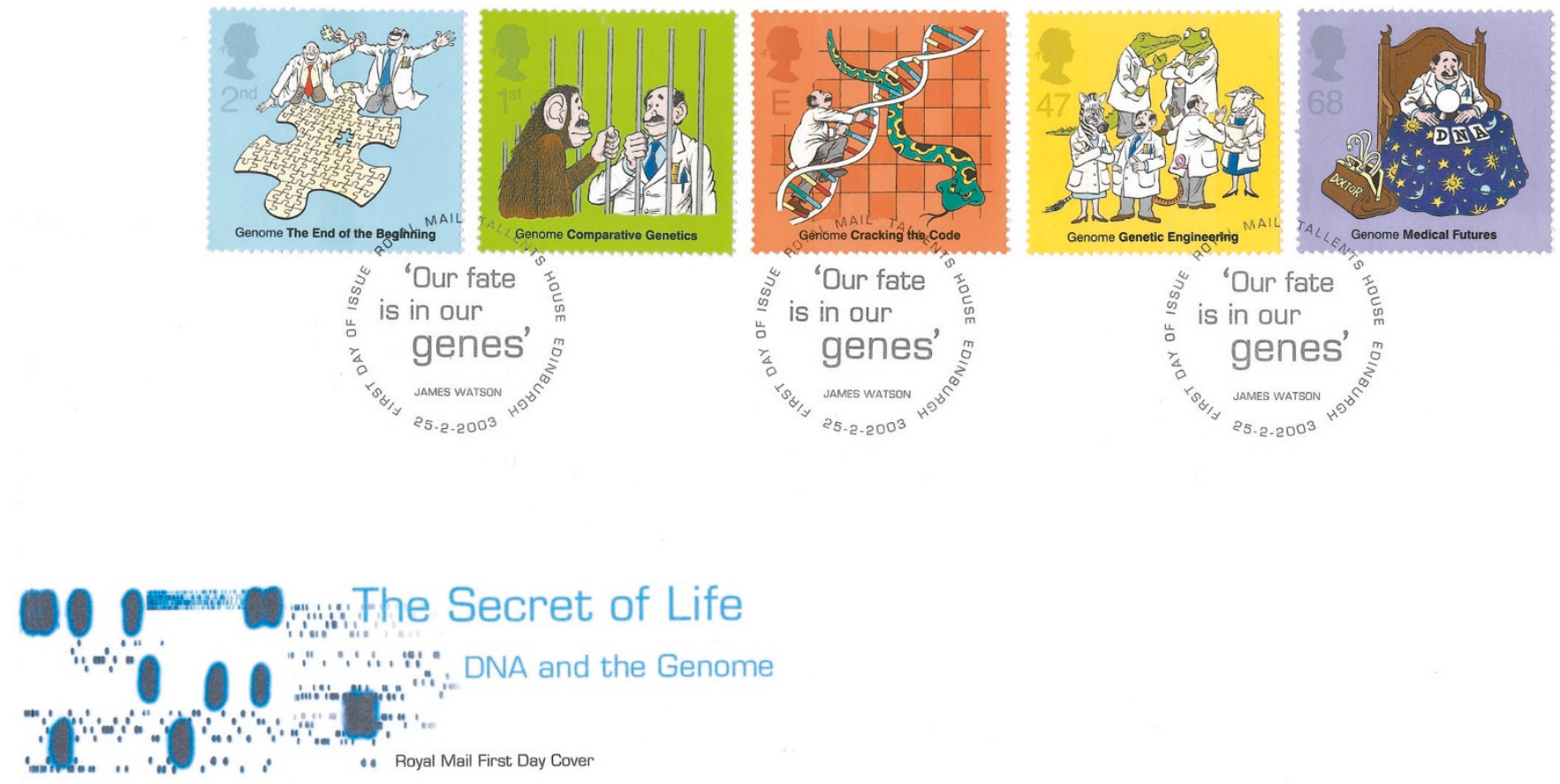

Royal Mail Tallents House 21 South Gyle Crescent Edinburgh EH12 9PB

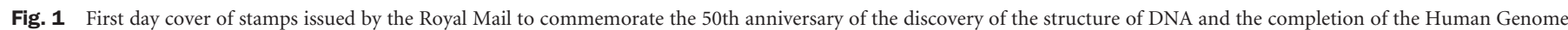
Project. "The Secret of Life" Stamps and First Day Cover @Royal Mail Group pic 2003. Reproduced by kind permission of Royal Mail. All rights reserved.

fective response to the critics, they-and they are we-must first listen carefully and nondefensively to what they have to say. I think that we should try to avoid the stance that some of our most prominent scientists took when confronted with public concern about recombinant DNA research. ${ }^{11}$ Their approach was to attribute the public's reservations to a combination of antiscience and ignorance. There's nothing wrong with us-it's the rest of the world that's wrong! There may well be kernels of truth in what they said, but I do not think that making the antiscience claim is going to be a productive way to deal with the issues, and it certainly will not resolve them. A better response would have been be to ask whether the accusation is a meaningful one, whether, in our case, it is really true that we are setting goals and engaging in practices that could-perhaps "should" would be a better word-be considered as eugenic.

\section{What is eugenics?}

The term "eugenic," originally suggested about 1883 by Galton, literally means "well-born," and if we were dealing with only this definition, there would perhaps be little to talk about. Much of what is done in life has just this goal in mind- to have healthy children free of disease and with prospects of leading productive and fulfilling lives. If looked at this way, most human societies could be regarded as being eugenic, with their members taking a large number of steps to increase the likelihood that their children will indeed be well-born, even though none of these activities has historically been regarded as being eugenic.
But, the definition of eugenics goes beyond well-born and introduces the notion of process as well as intention, of what we are willing to do to ensure that the children will be wellborn (Fig. 2). Thus, even in Galton's original usage, the concepts of "cultivation of race" and the production of "men of a high type" were present. ${ }^{12}$ In modern dictionaries, "eugenic" is defined as "relating to the production of good offspring," and "eugenics" as "a science that deals with the improvement (as by the control of human mating) of hereditary qualities of a race or breed." 13 Thus, the emphasis is on the control of the genetic
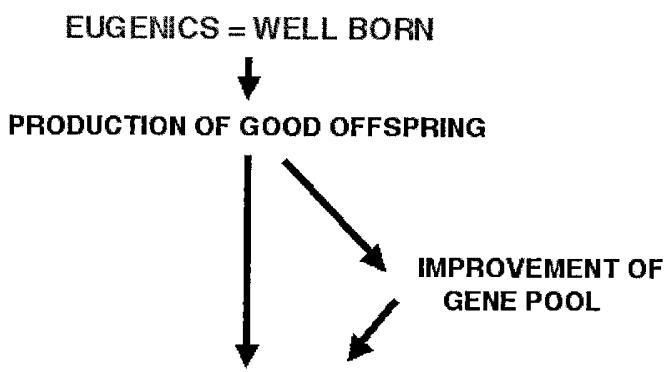

IMPROVEMENT OF GENETIC QUALITIES OF POPULATIONS (Race/Breed)

$$
\text { POSITIVE EUGENICS }
$$

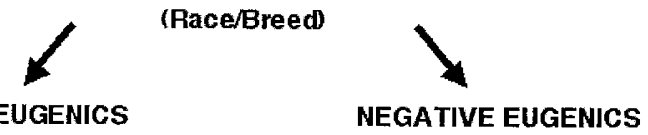

Encourage breeding of those with desirable characteristics

Fig. 2 Conceptual scheme of eugenics. 
properties of future offspring. Furthermore, it is implicit in all definitions that the traits that are the subjects of concern are indeed under genetic control and that they can be altered by making genetic changes and by improving the quality of the gene pool. Social and other environmental factors were thought to have relatively little effect.

The early concepts of eugenics as developed principally in England were derived from the belief that the upper (AngloSaxon) social classes were in danger of being diluted by the expansion, because of their higher birth rates, of the lower social classes and the allegedly inferior races. Galton's proposed solution to the problem was along the lines of positive eugenics - the encouragement of the breeding of those among the upper classes who possessed the desirable characteristics. However, he also allowed for more than that - for, as he put it, "whatever tends to give the more suitable races or strains of blood a better chance of prevailing over the less suitable than they otherwise would have had." ${ }^{14(\mathrm{p} 30)}$ Thus, even if the original notion was of positive eugenics, the actual implementation of eugenic principles very quickly began to run along negative eugenic lines. Rather than permit the Darwinian survival of the fittest to control the gene pool, the object was to ensure the nonsurvival of those considered to be unfit.

The principal means of implementing negative eugenics were by discouraging or preventing the reproduction of the unfit by prevention of marriage and of racial mixing, institutionalization, sterilization, and sometimes castration (Fig. 3). Added to this were quotas on the immigration of the supposed unfit and a general stigmatization of and discrimination against them. And, if this was not sufficient, abortion was employed to prevent their birth. Although all of this was theoretically voluntary, it rapidly became compulsory in many countries abroad and in many states in the United States.

However, it is, of course, in Nazi Germany that eugenics reached its ultimate and most terrible application-the Holocaust, with its wholesale extermination of millions of Jews, gypsies, homosexuals, mentally retarded, epileptics, mentally ill, and others deemed unworthy of life and certainly of reproduction (Fig. 4). This was to be the ultimate cleansing of the gene pool. No longer was breeding of the undesirable to be

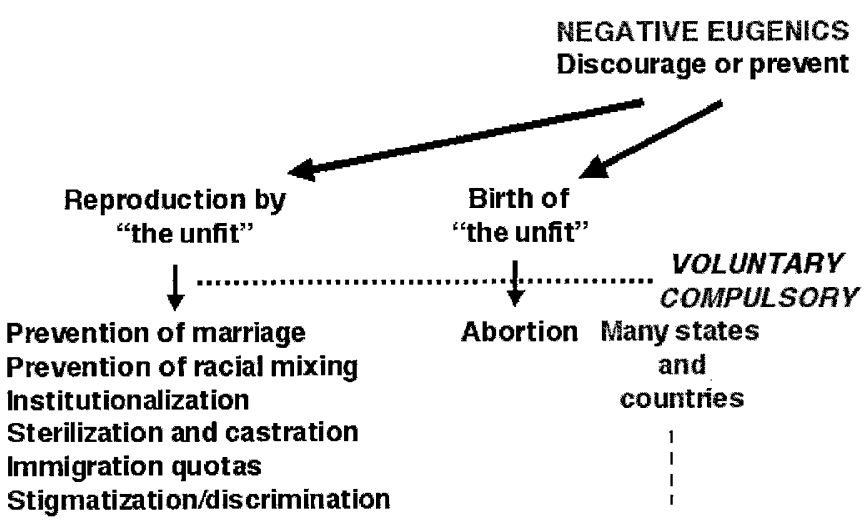

Fig. 3 Implementation of negative eugenics in many countries and states.

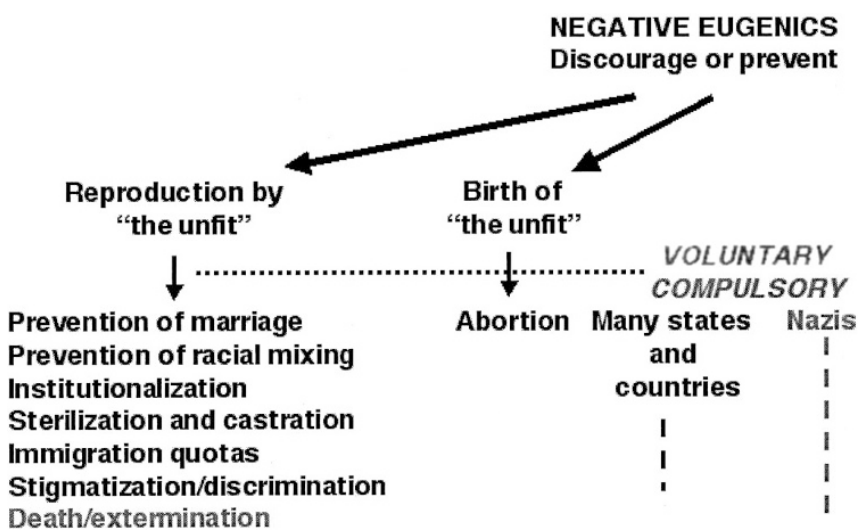

Fig. 4 Implementation of negative eugenics in Nazi Germany.

controlled-rather, the breeders who were thought to carry the undesirable genes were to be eliminated altogether.

As this mainline eugenics was flourishing in Nazi Germany, its popularity in other countries was decreasing. It was replaced by a so-called "reform eugenics," which did not include the Nazi approach and called into question the unscientific basis of much of the original eugenics and rejected the blatant racism and antifeminism that characterized it. However, this was not a rejection of the basic goal of eugenics but only of the excesses and unscientific attitudes that characterized it. So, despite the change in attitudes, laws providing for voluntary (although very often coerced) and compulsory sterilization were passed in more than half of the American states and in several countries of Northern Europe, and sterilizations under these laws were carried out into the 1960s_-right here in San Diego [the city in which this address was given]!15

In the latest iteration of reform eugenics, it was argued that what was required was a combined positive and negative eugenic approach-increasing the proportion of children born to those who achieve most and decreasing the proportion of children born to those with least achievement, all of this to be voluntary, of course. ${ }^{16}$ In addition, there was to be a voluntary

\section{REFORM EUGENICS}

\section{IMPROVEMENT OF GENETIC QUALITIES OF POPULATIONS}

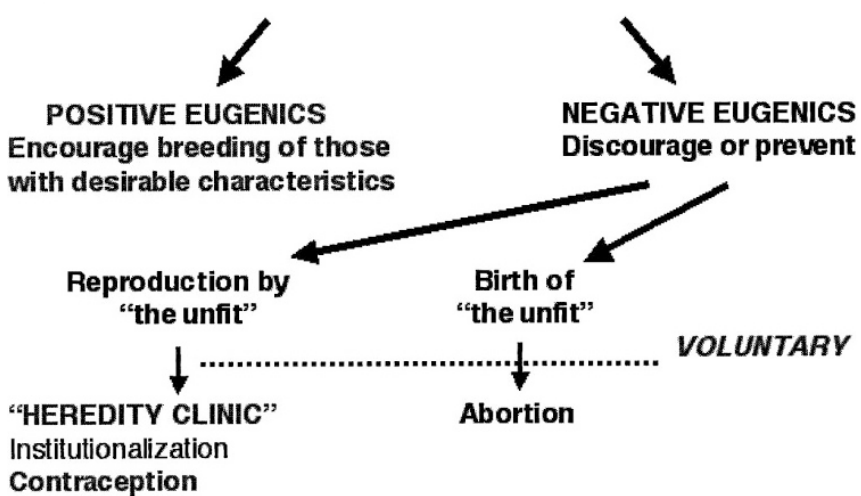

Fig. 5 Reform eugenics, as viewed by Osborn. ${ }^{16,17}$ 
reduction of the incidence of deleterious genes by means of the heredity clinic (which is equated to genetic counseling), institutional care, and the expanded use of contraception (Fig. 5). And, lest there be any misunderstanding, modern genetic counseling is described as being "in a special sense a eugenic activity. . . a form of negative eugenics, in that it attempts to prevent the conception or birth of individuals with most serious forms of maldevelopment..."17

\section{Eugenics as practiced was intrinsically wrong}

Given its history, there is no question that eugenics as it was actually practiced was wrong. Whether positive or negative, it violated fundamental human rights in numerous ways. It was coercive, discriminatory, and racist. It substituted control by the state for personal choice and autonomy. It denigrated and stigmatized the disabled and others deemed, for whatever reasons, as being unfit. It deprived people of their ability to reproduce, of their freedom, and, in the extreme, of their lives. The effects of the various eugenics movements were widespread, and they ranged from terrible to horrific.

\section{Eugenics as conceived was intrinsically wrong}

Not only was eugenics flawed in its applications, it was flawed in its basic genetic assumptions. The first was the belief in genetic determinism, the belief that all of the undesirable diseases and traits that the eugenicists were anxious to eliminate were genetically predetermined and, as a result, not alterable by environmental alteration. This notion is a major conceptual foundation for eugenics and, like eugenics, is a target for attack in its own right. The second flaw was the assumption that there were simple genetic explanations-in the extreme, recessive inheritance-for many, if not all of the traits of greatest interest to the eugenicists - criminality, alcoholism, psychiatric illness, and mental retardation. Indeed, as eminent a geneticist as R.A. Fisher argued that the incidence of "feeblemindedness" could be reduced by as much as $17 \%$ to $36 \%$ in one generation by "segregation or sterilization" of affected individuals. ${ }^{18}$

In addition to being genetically wrong, eugenics as originally conceived was also morally wrong. This was the conclusion reached by Buchanan, Brock, Daniels, and Wikler who conducted an interesting ethical autopsy of eugenics. ${ }^{14}$ In this autopsy, they considered many issues of importance to ethicists, the most important to them being the issue of justice, and this is what they had to say:

The eugenics movements of 1870-1950 insisted. . . that humankind. . . stood to gain a large benefit (more able, fit people) if humans would submit to the kind of breeding programs that had been used to improve plants and livestock. But who would benefit, and at whose expense? The internal logic of eugenics provides the answer. The "underclass" is simultaneously the group of people whose genes were not wanted and the people who, through involuntary sexual segregation, stigmatization and denigration, sterilization, and even murder, paid the price. The injustice of this distribution of benefits and burdens is evident. ${ }^{14}(\mathrm{p} 42-55)$
From this and the considerations discussed earlier, I think that it is fair to conclude that eugenics both as actually practiced and as originally conceived was intrinsically wrong, and I now want to turn to the question posed in the title of this address: is modern genetics the new eugenics? This is indeed a very broad question, and I shall restrict myself to consideration of just one aspect of modern medical genetics: prenatal diagnosis. The questions then are whether prenatal diagnosis is eugenics and, more particularly, whether it manifests the attributes that made eugenics intrinsically wrong.

\section{Is prenatal diagnosis eugenics?}

In the strictest sense, the question of whether prenatal diagnosis is eugenics translates into another question: does prenatal diagnosis seek to ensure the birth of well-born children? The answer is quite straight forward: yes, it does indeed seek to ensure the birth of well-born children! However, if we go to the broader conception of eugenics as seeking to improve the genetic qualities of populations, the answer is clearly no! Populations and gene pools are not the point at issue.

So much for definitions! We can then ask whether prenatal diagnosis is based on the basic assumptions underlying the eugenics of the past- unproven genetic mechanisms and genetic determinism. As currently practiced, the answer again is no.

However, these are not really the most important questions. The real issue is whether prenatal diagnosis as presently practiced exhibits the attributes that made the practice of eugenics wrong in the past: coercion and abrogation of reproductive freedom, state control, discrimination and racism, denigration and stigmatization of the disabled, and deprivation of life. Let's consider each of these in turn, starting with the matter of coercion.

Several commentators have suggested that prenatal diagnosis and selective abortion are subject to a variety of forces that are coercive in nature. Their concerns can be summarized in five statements:

What is routine is, by its very nature, coercive. The very fact that prenatal diagnosis and screening are widely available may be considered as implying that they should be used. ${ }^{19}$

The context in which they are operating prevents counselors from being truly even-handed and unbiased when laying out possible options. The existence of a test may be regarded as implying not only that it should be used, but also that the condition being screened or tested for is one that should be avoided. Therefore, even with the best of intentions, it is claimed, counselors cannot truly act in a nondirective manner when it comes to helping the potential parents to decide whether testing should be done at all or, if an adverse test outcome is obtained, whether the pregnancy should be terminated.,20,21

Pressure to be tested is exerted by those who offer prenatal testing, often for their own purposes. This is based on the assertion that the rationale for offering prenatal diagnosis and screening is not only or even really medical, but also legal- to ward off potential malpractice suits. ${ }^{4}$ 
When fetal abnormality is detected, there may be medical or social pressure to abort the pregnancy. Although this pressure may sometimes be overt, for most pregnant women with abnormal fetuses, any external pressure to abort is more likely to be the result of perceived societal pressure against having abnormal babies. ${ }^{19,22,23}$

Even in the absence of external pressure, the process of prenatal diagnosis has an internal momentum that drives toward abortion. Given what has already been said about what the existence and performance of prenatal testing imply, the contention that "it is very difficult to get off the roller coaster once embarked" can readily be understood. With minor exceptions, the process is usually undertaken with the expectation-implicit if not explicit-that abortion will be the likely outcome if fetal abnormality is diagnosed. ${ }^{19}$

In sum, then, although there is no claim that women are truly coerced into undergoing prenatal diagnosis, I do not think that we can avoid the fact that there are indeed forces at work, some subtle and others not so subtle, that do exert a coercive force toward utilization of prenatal diagnosis and termination of pregnancy if an abnormal fetus- however that is defined-is detected.

As you can see from this list, the genetic counselor is perceived as playing a major role in the prenatal diagnosis process and his or her ability to be neutral or impartial, as current dogma requires, has been called into question. Just what the counselor should be doing is, of course, a very major question.

I now turn to the second negative attribute of eugenics practice and ask the following question: what is at the role of the government in prenatal diagnosis? With the possible exception of China and a few other countries, governments do not appear to be mandating prenatal diagnosis and selective abortion. Nevertheless, governments are very much in the business of prenatal diagnosis, and it is necessary to consider why this is. Troy Duster capsulates the issue very neatly: When the state pays for genetic screening, counseling, and treatment, it becomes the "third party" in the transaction. Here is the final inherent contradiction: the state cannot both (a) insist that such genetics disorder control programs are designed to assist the individual, whatever his or her choice, and then (b) argue cost effectiveness of service utilization on the grounds that such services as utilized in the aggregate cost the public less money. ${ }^{3}$ (p76)

This contradiction that has troubled me quite a bit, and the paragraph above a table from a report on the California triple marker screening program is an example of what about it has troubled me. ${ }^{24}$ "It is useful to reflect on the missed opportunities for the avoidance of birth defects...." And what missed opportunities are being spoken about? The table make this clear-they are the numbers of women who did not elect to terminate a pregnancy after the detection of an abnormal fetus-about $50 \%$ overall with a chromosomal abnormality and $30 \%$ with a neural tube defect. However, Cunningham and Tompkinson ${ }^{24}$ are probably correct in asserting that cost-benefit analyses of genetic services are probably here to stay, and the New England Regional Genetics Group Social and Ethical
Concerns Committee ${ }^{25}$ agrees. Therefore, it would be well if the cautions of this group could be heeded. They point out that cost-benefit analyses attempt to convert seemingly incommensurable units (cost and benefits to patients, families, and society) solely to monetary terms. In doing so, they have several ethical limitations, in particular the frequent overlooking or inadequate weighting of nonmonetary costs and benefits and the omission of considerations of equity and fairness because costs and benefits are aggregated across all individuals concerned. The latter results in benefits to individuals being compared with benefits to society, a situation that may not be the most ethical one if the interests of society are regarded as paramount. Genetics, which deals with analysis of risk and variable outcomes, is considered to be "particularly recalcitrant to accurate and value-neutral" analysis.

Nevertheless, perhaps we need to look past the rhetoric and consider what might be accomplished. If we can agree that it is good to give prospective mothers the opportunity to have their pregnancies tested-if that is what they truly wish, if their choice to do so is truly informed and voluntary, and if they fully understand the implications of being tested-then perhaps we can look beyond the cost-benefit analyses and accept the state-run screening programs on that basis. If such analyses are what are needed to satisfy the requirements of governmental due diligence, so be it, but let us not believe that they are what truly matters.

I am going to skip over the issue of discrimination since I do not see it as a major problem except possibly in a reverse context. If discrimination exists it is that certain ethnic groups are bring denied access to prenatal diagnostic services rather than being forced to undergo it. However, the next question is of paramount importance: does prenatal diagnosis denigrate and stigmatize the disabled? Prenatal diagnosis programs, however they may be justified, clearly do have as their goal the prevention of the birth of children with various types of disability. Similarly, even if not targeted against specific racial or ethnic groups, negative eugenic policies were certainly aimed at persons with disabilities, particularly those associated with mental retardation and illnesses believed to be hereditary. It is, therefore, not difficult to understand how prenatal diagnosis has been viewed as allying itself with the eugenic denigration of the disabled and as implying (rather than stating openly, as did many of the eugenic programs of the past) several negative things about the disabled: that they, rather than their disability or their treatment by society, are the problem ${ }^{26}$; that they are less desirable members of society and thus have no place in our society ${ }^{24,28}$; that disability is inherently bad and that people with disabilities lead blighted, tragic lives ${ }^{27}$; and that their lives are not worth living and, therefore, that they should not exist. ${ }^{21,29}$

Therefore, the critics believe, the new genetics and old eugenics are not very different in that they both promote exclusion of the disabled rather than inclusion. ${ }^{14}$ Accusations against prenatal diagnosis and genetic counseling based on these types of thinking have been made by several groups of persons with congenital conditions [I had to catch myself when 
I was writing this. I originally wrote "defects," a clearly prejudicial term in the present context.], particularly by persons with dwarfism, spina bifida, and deafness, as well as by the broader disability rights community. To get a real sense of how a group of disabled person feels, we should look at the Position Statement on Genetic Discoveries in Dwarfism posted by the Little People of America (LPA) on their Web site:

\begin{abstract}
What will be the impact of the identification of the genes causing dwarfism, not only on our personal lives but on how society views us as individuals?.. Some members [of LPA] were excited about the developments that led to the understanding of the cause of their conditions, along with the possibility of not having to endure a pregnancy resulting in the infant's death [from homozygous achondroplasia]. Others reacted with fear that the knowledge from genetic tests such as these will be used to terminate affected pregnancies and therefore take the opportunity for life away from ourselves and our children. ${ }^{30}$
\end{abstract}

The Little People of America have had a long and positive history of interactions with medical genetics. Therefore, one cannot read such a statement without coming away with the feeling that persons with disabilities are indeed deeply threatened and affected by the rhetoric of the proponents of prenatal diagnosis. However, this is not all that the statement says:

The common thread throughout the discussions was that we as short statured individuals are productive members of society who must inform the world that, though we face challenges, most of them are environmental (as with people with other disabilities), and we value the opportunity to contribute a unique perspective to the diversity of our society. ${ }^{30}$

If there is any question in your mind that this is an important and highly emotional issue, the cover from the New York Times Magazine of February 16, 2003 with the headline, "Should I Have Been Killed at Birth? The case for my life,"31 should convince you otherwise. Although the article itself is concerned with a debate between Princeton philosopher Peter Singer and the author, Harriet McBryde Johnson, whose picture in a wheelchair is shown on the cover, over the euthanasia of newborns with disabilities, it might just as well have been about prenatal diagnosis and abortion.

I have thought a lot about the arguments that are encompassed by the disability rights critique (for summary, see Appleyard ${ }^{21}$ ). This thinking has been particularly focused by my involvement with the National Down Syndrome Society, which brought me into extensive contact with many persons with Down syndrome and with their parents and friends- not in the formal role of physician and teacher and research scientist, but as their advocate and friend. In the latter capacity, I was forced to look at the world from their point of view and to ponder why it was so uncomfortable for me to speak about prenatal diagnosis in their presence. I shall not go into the arguments on both sides of the disability rights critique. Nevertheless, I do have to say that while I do not accept the arguments of the disability rights critique as they apply to prenatal diagnosis, I am nevertheless greatly troubled by what the critique says about how human and medical geneticists are per- ceived and about what they—about what we—are doing. Lynn Gillam said it very well:

\begin{abstract}
For people with disabilities, to have someone else look at their lives from the outside, and make judgments about how fulfilling and how happy they are, must be deeply offensive. . . However,... the fact that a practice is offensive to some section of the community does not make it morally wrong to engage in it, or make it to be discriminatory to the minority. . . This does not mean that offense or psychological distress caused to people with disabilities does not matter. It certainly does, and there is good moral reason to try to avoid or at least to minimize such effects. ${ }^{32}$
\end{abstract}

I come now to the final question regarding prenatal diagnosis and eugenics- does prenatal diagnosis involve deprivation of life? The answer, in real terms, is certainly yes. Whatever the theory might be with regard to prenatal diagnosis as merely providing information, prenatal diagnosis and abortion are inextricably linked. Without entering into the arguments pro and con, I have made my peace with the right of parents to terminate pregnancies that are unwanted. Nevertheless, I must confess that I agree with Bryan Appleyard that "whatever one's feelings about abortion, everybody must agree that this does not amount to a very positive achievement for this new form of medicine." ${ }^{1}(\mathrm{p} 129)$

So, is prenatal diagnosis eugenics?

- Does it seek to ensure the birth of well-born children? YES, it certainly does!

- Does it seek to improve the genetic qualities of populations? NO, it does not!

- Does it adhere to the basic assumptions underlying the eugenics of the past- to unproven genetic mechanisms or to genetic determinism? Again, the answer is NO.

Does prenatal diagnosis exhibit the attributes that made the practice of eugenics intrinsically wrong?

- Is there coercion and abrogation of reproductive freedom? I would say NO, but as I mentioned earlier, there may well be coercive elements at play.

- Is there state control? Again, the answer is NO, but the state-in the literal sense, the states—-do seem to have a vested interest in the outcome.

- Is there discrimination and racism? Again, NO. These do not appear to be major issues except perhaps from the point of view of lack of access to services rather than over utilization.

- Is there denigration of the disabled? I would say NO, but there are many who feel very strongly that it does.

- Finally, is prenatal diagnosis murder? Prenatal diagnosis may certainly lead to abortion and deprivation of fetal life, but NO, I do not equate this with either euthanasia or murder.

So, by the strictest definition- "eugenic" being equated with "well-born" - prenatal diagnosis is eugenics. But, it is not concerned with populations, it does not adhere to the basic 
assumptions underlying eugenics of the past, and, as currently practiced, it does not truly exhibit attributes that made the practice of eugenics intrinsically wrong. Therefore, from my point of view, prenatal diagnosis is, at worst, eugenics in name only. BUT!!!. . . But, I would hope that we all agree that there is still much for us to think about with regard to what we are now doing, and even more to think about with regard to what we might be doing in the future-about carrier screening before marriage, presymptomatic genetic testing, preimplantation diagnosis, gene therapy, and the search for genetic components of behavior and intelligence.

My view of how the genetics community should address the public concerns about a resurgence of eugenics is philosophically quite close to the view expressed by Harper and Clarke in the introduction to their very insightful and valuable volume, Genetics and Society and Clinical Practice, which appeared in 1997, and I shall close by quoting their comments on the subject:

... a questioning and critical attitude, both to new developments and to established concepts, is important and necessary in a field like medical genetics, which inevitably impinges on so many controversial areas... There is all the more reason to maintain a critical attitude in the light of the disastrous abuses that have already been carried out in the name of genetics by professionals and by an entire social system in the past. . . We need to keep alive our awareness of these past abuses and to maintain our vigilance that new developments are not misused in the future. . . We feel that it is much healthier for this questioning to come from within the genetics community, rather than for those in the field to 'close ranks' against external criticism. ${ }^{20(\mathrm{p} 3)}$

\section{ACKNOWLEDGMENT}

The research for this presentation was performed in part in 2000 while Dr Epstein was a Scholar in Residence at the Rockefeller Foundation Bellagio Study \& Conference Center, Bellagio, Italy.

\section{References}

1. Future visions. Time 2003;161:60-61.

2. Kolata G. Genetic revolution: how much, how fast? New York Times February 25, 2003:F6.

3. Duster T. Backdoor to Eugenics. New York: Routledge, 1990.

4. Dyck AJ. Eugenics in historical and ethical perspective. In: Kilner JF, Pentz RD, Young FE, editors. Genetic ethics: Do the ends justify the genes? Grand Rapids, Michigan: Paternoster Press, WB Eerdsmans Publishing Co, 1997:25-39.
5. Wertz DC. Eugenics is alive and well: A survey of genetic professionals around the world. Science in Context 1998;11:493-510.

6. Holden C. More men ready for cloning. Science 2003;299:41.

7. Fox JL. Eugenics concerns rekindle with application of gene therapy and genetic counseling. Nat Biotech 2002;20:531-531.

8. Dawkins R. Forward. In: The genetic revolution and human rights. Oxford: Oxford University Press, 1999:v-xviii.

9. Paul DB. The politics of heredity: Essays on eugenics, biomedicine, and the naturenurture debate. Albany: State Univ of NY Press, 1998:97.

10. American Society of Human Genetics, 1998. Available at: http://www.faseb.org/ genetics/ashg/pubs/policy/pol-30.htm. Accessed October 1, 2003.

11. Turney J. Frankenstein's footsteps: Science, genetics, and popular culture. New Haven, Yale University Press, 1998:192-193.

12. Oxford English Dictionary. Oxford: Clarendon Press, 1970;3:319.

13. Webster's New Collegiate Dictionary. Springfield, Massachusetts: G.C. Merriam Co: $1981 ; 390$.

14. Buchanan A, Brock DW, Daniels N, Wikler D. From chance to choice. Cambridge: Cambridge University Press, 2000.

15. Abate T. California's role in Nazis' goal of purification. San Francisco Chronicle March 10, 2003:E1.

16. Osborn F. The future of human heredity: An introduction into eugenics in modern society. New York: Weybright and Talley, 1968.

17. Osborn FH, Robinson A. Eugenics. In: The New Encyclopedia Britannica, 15th ed. Chicago: Encyclopedia Britannica, 1987;19:726-727.

18. Fisher RA. The elimination of mental defect. Eugenics Rev 1924;16:114-116.

19. Green J, Statham H. Psychosocial aspects of prenatal screening and diagnosis. In: Marteau T, Richards, editors. The troubled helix: Social and psychological implications of the new human genetics. Cambridge: Cambridge University Press, 1996:143-165.

20. Harper P, Clarke A. Genetics and society and clinical practice. Oxford: BIOS Scientific Publishers, 1997.

21. Appleyard B. Brave new worlds: Staying human in the genetic future. New York: Viking, 1998.

22. Hubbard R, Wald E. Exploding the gene myth: How genetic information is produced and manipulated by scientists, physicians, employers, insurance companies, educators, and law enforcers. Boston: Beacon Press, 1999:27.

23. Hume J. Disability, feminism and eugenics: Who has the right to decide who should or should not inhabit the world? 1996. Available at: http://www.wwda.org.au/eugen.htm. Accessed

24. Cunningham GC, Tompkinson DG. Cost and effectiveness of the California triple marker prenatal screening program. Genet Med 1999;1:200-207.

25. New England Regional Genetics Group Social, and Ethical Concerns Committee Statement on cost-effectiveness and cost-benefit analysis. 1999. Available at: http:// www.nergg.org/pop_cost_benefit.html. Accessed

26. Parens E, Asch A. The disability rights critique of prenatal genetic testing: Reflections and recommendations. Hasting Cent Rep 1999:S1-S22.

27. Wikler W, Palmer E. Neo-eugenics and disability rights in philosophical perspective. In: Fujuki N, Macer DRJ, editors. Human genome research and society: Proceedings of the Second International Bioethics Seminar in Fukui. 1992. Available at: http://zobell.biol.tsukuba.ac.jp/-macer/HGR/HGRDW.html. Accessed

28. Headings $\mathrm{H}$. The present state of genetic knowledge and implications for genetic screening. In: Kegley JAK, editor. Genetic knowledge: Human values and responsibility. Lexington, KY: ICUS, 1998:113-122.

29. Nelkin D, Lindee MS. The DNA mystique: The gene as a cultural icon. New York: Freeman 1995;171.

30. Little People of America, 2003. Available at: http://www.LPAOnline.org/resources_faq.html. Accessed

31. Johnson HM. Unspeakable conversations. New York Times Magazine February 16 , 2003:50.

32. Gillam L. Prenatal diagnosis and discrimination against the disabled. J Med Ethics 1999;25:163-171. 